\title{
炭酸水素ナトリウムとクエン酸の化学反応を用いた 小型増圧ポンプを有する携帯型空気圧源の提案*
}

\author{
奥 井 学**, 名 倉 裕 貴**, 飯 川 伸 吾** \\ 山田泰 之**, 中 村太 郎**

\section{Proposal of Portable Pneumatic Power Source Using Chemical Reaction of Sodium Bicarbonate and Citric Acid with Small Sized Pressure Booster} \\ Manabu OKUI, Yuki NAGURA, Shingo IKKAWA, \\ Yasuyuki YAMADA, Taro NAKAMURA
}

This paper is concerned with portable pneumatic power source using chemical reaction of sodium bicarbonate and citric acid. Carbon dioxide generated in the chemical reaction is used as the compressed air. Both sodium bicarbonate and citric acid are inexpensive, nontoxic, and readily available. This paper is organized as follows. Firstly, the characteristics of the chemical reaction is surveyed and the appropriate pneumatic power source system is discussed. Secondly, a pressure booster that can achieve a stable air generation system without external power is described. Thirdly, the experiment using the prototype system is conducted to confirm the effectiveness of the proposed method.

Key words : Pneumatic power source, Chemical reaction, Pump

\section{1. 緒言}

空気圧駆動システムは様々な分野で用いられている．近 年では特に, 柔軟な動作が可能かつ, 軽量で高出力という 特性に着目した研究が多くなされている1,2).これらの装置 の駆動には主にエンジンや大型モータ駆動のコンプレッサ により生成される圧縮空気が利用されるが, これらの大 型／高重量の空気圧源は装置のモバイル化の障壁となって いる. 携带型空気圧源によりシステムのモバイル化が可能 となれば，空気圧システムの用途が大きく広がると考える. そのため, これまでに多くの携帯空気圧源が開発されて いる. その一つが小型のコンプレッサをバッテリーで駆動 する方法である ${ }^{3)}$. 本方式はバッテリーを電源としモータ の駆動により圧縮空気を生成する. しかし, 電気エネル ギーから圧縮空気を生成するためエネルギー効率に課題が あり，また高圧印加時に圧縮空気の吐出流量が小さいとい う点も問題である. 一方，ガスの燃焼 ${ }^{4)}$ や燃料電池の放 電 /充電 ${ }^{5)}$ を利用した空気圧アクチュエータの駆動方法も 開発されているが，安定的に十分な圧力の圧縮空気を生成 することは実現していない. また, 空気圧源の代わりに夕 ンクに圧縮空気をためる手法も考えられるが，数 $\mathrm{MPa}$ 高

\footnotetext{
*平成28年10月20日 原稿受付

**中央大学

(所在地：東京都文京区春日 $1-13-27$ )

(E-mail : nakamura@mech.chuo-u.ac.jp)
}

圧貯蔵では容器の耐圧性向上のためタンクが重くなり, 低 圧貯蔵では十分な圧縮空気量を確保するためにはタンクが 大型化してしまう。これらを顧みて, 北川らはドライアイ スの 3 重点を利用した空気圧源を開発している は0.42MPaの気体を安定的に放出できることが確認されて いるが，ドライアイスを使用していることから常温下で圧 縮空気のエネルギーを貯蔵することができないなどの課題 が存在する.

本研究ではこれらの課題を解決するために，炭酸水素ナ トリウムとクエン酸の化学反応により発生する二酸化炭素 を利用する方法に着目した．炭酸水素ナトリウムと酸の反 応の空気圧源としての利用はこれまでにも検討されており， 動力を用いずに0.7MPa以上の高圧が発生可能という特性が 確認されている7),8). しかし，いずれも発生最大圧力の測定 などにとどまり実際の空気圧システムを駆動するといった 検討は行われていない. そこで本報では, 本化学反応の空 気圧源としての特性についてより詳細に調査し, 化学反応 を利用した空気圧源の構成について検討する. また外部動 力を用いずに反応を安定的に制御する小型増圧ポンプにつ いて述べ，最後に試作した空気圧源による空気圧人工筋肉 の駆動実験を行い，提案手法の有効性を確認する.

\section{2. 空気圧源の構成}

\section{1 化学反応の基本原理}

式(1)に示すように，炭酸水素ナトリウムとクエン酸，水 を混合することで二酸化炭素が発生することは広く知られ 
ている.これらの物質は一般的に清掃用に利用されており， 安価で保存が容易, かつ簡易に入手および廃裹が可能であ る. また本反応により生成される二酸化炭素, 水, クエン 酸三ナトリウム（化学式： $\mathrm{Na}_{3} \mathrm{C}_{6} \mathrm{H}_{5} \mathrm{O}_{7}$ ) の混合物は無毒 であり，一般的な下水に廃裹することが可能であるだけで なく, 飲料用水としても利用可能である.

$$
\begin{aligned}
& \mathrm{C}_{6} \mathrm{H}_{8} \mathrm{O}_{7}+3 \mathrm{NaHCO}_{3} \\
& \quad \rightarrow \mathrm{Na}_{3} \mathrm{C}_{6} \mathrm{H}_{5} \mathrm{O}_{7}+3 \mathrm{H}_{2} \mathrm{O}+3 \mathrm{CO}_{2} \uparrow
\end{aligned}
$$

\section{2 発生圧力と発生気体量}

提案する化学反応を利用した空気圧源は，身に着けなが ら移動が可能であり，できるだけ使用者に負担を与えない ことが望ましい，すなわち軽量かつ小型であることが求め られる。.また，空気圧システムの駆動に十分な圧力を発生 可能かどうかという点も重要である，そのため，発生可能 な最大圧力と混合物質量あたりの発生積算流量を実験によ り調查した。

実験装置をFig. 1に示す、装置は500mLのボトルおよび測 定用空圧回路から成る. ボトルの内部には炭酸水素ナトリ ウムとクエン酸が水と分離された状態で格納されている. ボトルAは内部に外部磁力により可動する機構を持ち, 密 封状態を保ったまま混合を行うことが可能である，実験で は，初めに 2 方弁を閉じた状態で磁力操作により混合を行 う. 次に，混合を促すためボトルを振る．圧力に変化が無 くなるまでボトルを振り，その後 2 方弁を開放し流量を測 定する，流量計はSMC製PFMB7201-02-A-M，圧力計は PISCO製SEU11-6UAを使用した。実験は $25^{\circ} \mathrm{C}$ の屋内で行い， 標準状態気体体積の算出は大気圧を0.1013MPaとみなし計 算した. 実験は 3 回行い，その平均值を測定值とした.

実験に使用した物質の分量をTable 1に，測定結果を Table 2に示す．結果より，本手法は空気圧システムの駆動 に十分な圧力が発生可能なことが確認できた．また，発生 気体の積算流量は6.54NLであり，これは $1 \mathrm{~mol} の$ 気体の体積 を22.4NLとした場合の理論值である6.72NLとほぼ一致して いる. これは長さ $180 \mathrm{~mm}$ の軸方向繊維強化型人工筋肉 ${ }^{7}$ を 0.3MPaの印加圧力で約14回駆動可能な気体量であり，携带 空気圧源として使用に耐えうるだけの流量を発生可能であ ると考える.

Table 1 Experimental condition

\begin{tabular}{|l|l|}
\hline Sodium bicarbonate & $25.2 \mathrm{~g}(0.3 \mathrm{~mol})$ \\
\hline Citric acid & $19.2 \mathrm{~g}(0.1 \mathrm{~mol})$ \\
\hline Water & $300 \mathrm{~mL}$ \\
\hline
\end{tabular}

Table 2 Experimental result

\begin{tabular}{|l|l|}
\hline Measured integrated flow & $6.54 \mathrm{NL}$ \\
\hline Measured pressure & $1.1 \mathrm{MPa}$ \\
\hline
\end{tabular}

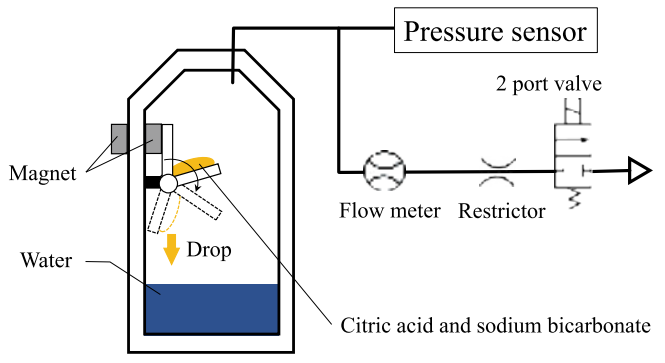

Fig. 1 Gas generating experimental setup

\section{3 水の分量と反応速度の関係}

水を溶媒とした化学反応において, 水の分量が反応速度 に影響することが広く知られている，安定した圧力と流量 を供給可能な空気圧源開発のため, 気体の発生スピードと 水の分量の影響について実験により調べた。

実験装置はFig. 1 と同様ものを使用した．実験では，バ ルブは常に開放状態にして置き, 密閉容器内にクエン酸 $9.6 \mathrm{~g}$ ，炭酸水素ナトリウム $12.6 \mathrm{~g}$ の混合粉末と水を分離して 封入し, 外部から磁力操作により混合した．混合開始から 180秒間の積算流量を測定した，水量は $10 \mathrm{~mL} ら ら 100 \mathrm{~mL}$

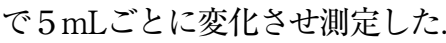

測定結果のうち，代表的なものをFig. 2に示す．本結果 から，水の分量が $25 \mathrm{~mL}$ の時に最も反応速度が速いことが 分かった．また，水量が $25 \mathrm{~mL}$ 以上の場合は反応速度は濃 度が高いほど早く, 水量が25mL以下では濃度が高いほど 反応速度が低下することが分かった，そのため，本化学反 応を空気圧源として使用する場合には，クエン酸と炭酸水 素ナトリウムの濃度を上記実験条件での水の分量が25mL

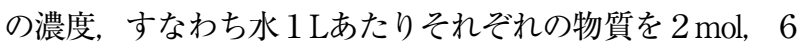
mol混合することが望ましいことが碓認できた.

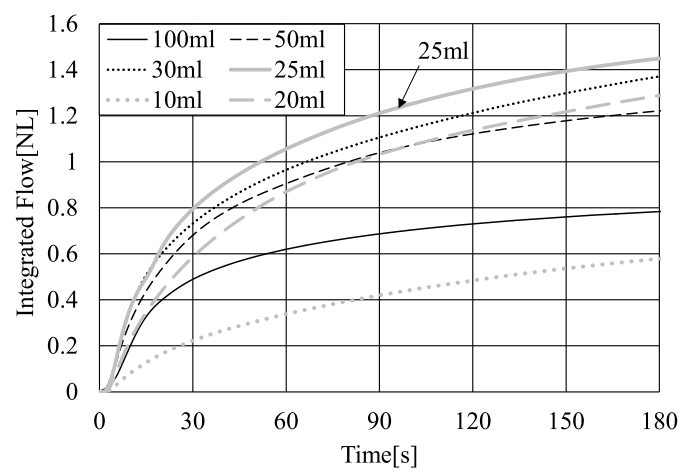

Fig. 2 Integrated flow rate of the chemical reaction

\section{4 反応を継続させる手法}

本化学反応は $1 \mathrm{MPa}$ 以上の圧縮空気を発生することが可 能であるため, 必要な空気量分の物質をあらかじめ混合し ておく場合には空気圧源内部の圧力が $1 \mathrm{MPa}$ 以上になる可 能性がある，容器内圧が $1 \mathrm{MPa}$ 以上となる場合，タンクに 
高い耐圧性が必要となるためタンクの高重量化を招く，そ のため, 発生圧力を適度に保つために, クエン酸と炭酸水 素ナトリウムを必要に応じて混合することが必要だと考え る. 加えて, 水の分量は反応速度に影響を与えるため, ぞ れぞれの物質を $2.3 て ゙$ 述べた混合比で反応させることが望ま しい.

クエン酸と炭酸水素ナトリウムを継続的に混合する手法 として, Fig. 3(a)に示す 2 物質を混合した粉体をスクリュー 搬送機などで水に投入する粉体投入方式が考えられる。 こ のような構成においては，水に投入する粉体量を制御する ことで容器内を任意の圧力に調整可能であるが, 装置全体 を高圧のタンク内に密封する必要があり, 構造が複雑化す る. 同様の理由から，どちらか一方の物質の水溶液に，も う一方の物質を粉体状態で投入する方式も課題が存在する と言える。

システムを簡素化するために，Fig. 3(b)のような液体注 入方式が考えられる. 本方式は空気圧発生タンクにあらか じめ粉体または液体を封入しておき，水溶液や水を注入す る方式である。この方式の場合, 圧力の高い容器内に液体 を送り込むためのポンプなどの増圧装置が必要であるが, システム全体を容器内に入れる必要がなくシステムの簡素 化が期待できる．また，反応物質の注入量もバルブの開け 閉めなどにより容易に制御が可能である。

他にも反応を継続させる手法は考えられるが，本研究で はFig. 3(b)の構成を前提に考察を進める。 この構成は, 水 と炭酸水素ナトリウムがあらかじめ封入された容器に, ク エン酸を注入する方式である. クエン酸濃度は，ポンプの 駆動量を最小限にするために飽和水溶液となる $3.8 \mathrm{~mol} / \mathrm{L} と$ する．また水・クエン酸・炭酸水素ナトリウムを $2.3 て ゙$ 求め た最適な分量比とするために, 圧力発生容器には $12.7 \mathrm{~mol} / \mathrm{L}$ の炭酸水素ナトリウム水溶液を, クエン酸と炭酸水素ナト リウムのモル比が $1 ： 3$ となる分量だけ封入しておく．実

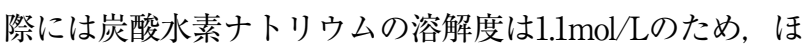
とんどの炭酸水素ナトリウムは解け切らずに個体として残 る. 本構成により, 常にクエン酸と炭酸水素ナトリウムの 飽和水溶液が混合され安定的な反応が可能となる. 加えて 混合が進むにつれ，クエン酸・炭酸水素ナトリウム・水の 分量比が2.3で求めた最適な比に近づいていき，最終的は2.3 の比とすることが可能である.

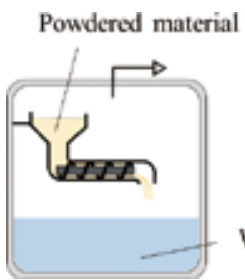

(a)

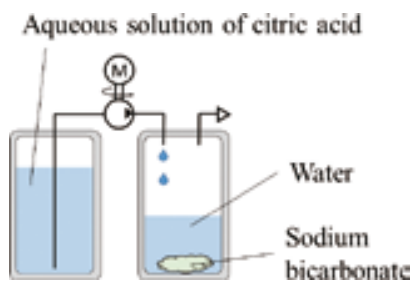

(b)
Fig. 3 Comparison of structure

\section{3. 増圧装置}

前章で提案した方式を採用する場合, クエン酸飽和水溶 液を送る増圧装置が必要となる，本章では，新たなエネル ギー源を必要とせずにラバーアクチュエー夕の排気で駆動 する増圧装置について述べる。

\section{1 構造}

空気圧ラバーアクチュエータは，ある印可圧力以下では 動作しない特性を持つ。例としてFig. 5に軸方向瀻維強化 型人工筋肉の収縮特性 ${ }^{7}$ を示す。人工筋肉は約 $0.125 \mathrm{MPa}$ では収縮しないことがわかる．本研究ではこのラバーアク チュエータが収縮し始める圧力を基底圧力と呼び，この基 底圧力を利用した増圧装置を提案する。

増圧装置の動作原理図をFig. 4に示す，本装置は軸方向 瀻維強化ゴムチューブと単動空気圧シリンダ，ターミナル およびチェック弁から成る，軸方向瀻維強化ゴムチューブ はFig. 6に示す構造となっており, 空気圧を印加した際に 軸方向が炭素繊維で拘束されているため, 径方向にのみ膨 張し長手方向には収縮する。 シリンダ内に流体が入った状 態で軸方向瀻維強化ゴムチューブに圧力を印加することで シリンダが押され，軸方向繊維強化ゴムチューブに印加し た圧力よりも高い圧を吐出する.

本増圧装置を利用した空気圧源のシステム全体図を Fig.7に示す. システムはラバーアクチュエータ，2 方弁, 3方弁, レギュレータ, リリーフバルブ, 増圧装置, クエン 酸水溶液の入ったボトル $\mathrm{A}$, 重層と水の入ったボトルBから 成る．まず，Fig.7に示すように 3 方弁は開き，2方弁は開 放状態としておき，ボトルBからの圧力によりラバーアク チュエータを駆動する. 次に 3 方弁と 2 方弁を同時に切り 替え, アクチュエータの排気圧力により増圧装置を駆動し ボトルAのクエン酸水溶液がボトルBに注入される。これ らの $2 つ の$ 状態を繰り返すことでラバーアクチュエータの 駆動と増圧装置によるクエン酸の注入が交互に行われる。

\section{2 特性}

本節では，増圧装置の特性を物理モデルから考察する。 装置の各パラメータをTable 3に示す。 各パラメータは
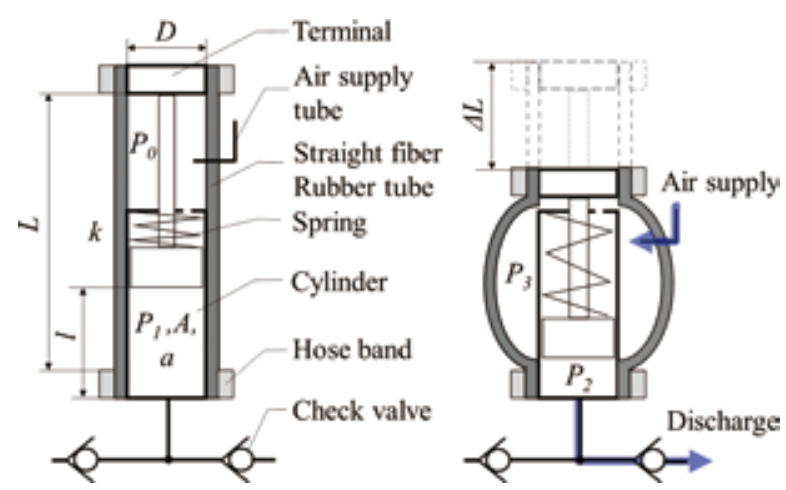

Fig. 4 Schematic of the pressure booster 


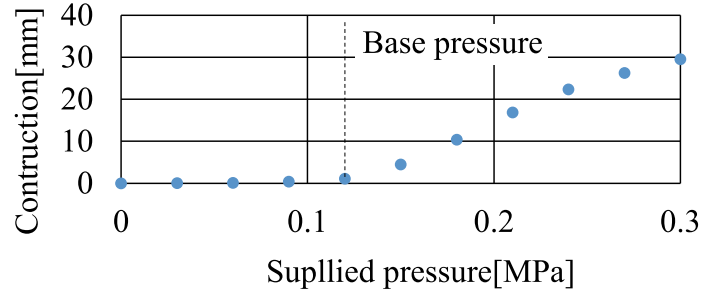

Fig. 5 Applied pressure and shrinkage of rubber actuator

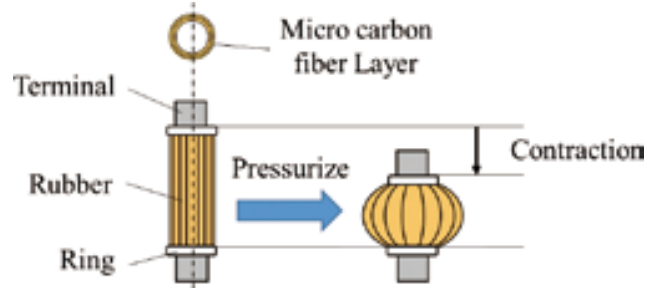

Fig. 6 Principle of straight fiber artificial muscle

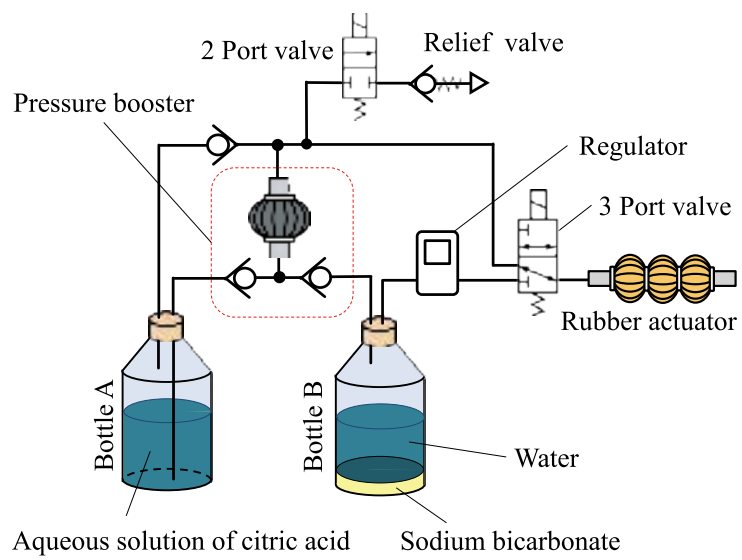

Fig. 7 Continuous air generation system

Fig. 4と対応している. なお本モデルでは，ばねは押しば ねを前提としたが, 本増圧装置の駆動原理上ばねを有して いないシリンダや引きばねを有するシリンダについても同 様の動作が可能である。

軸方向繊維チューブのシリンダを押す力を $F_{m}$, シリンダ 内のバネ力を $F_{k}$ とする. すると, 力のつり合いより式(2)が 成り立つ。

$$
F_{m}+F_{k}+P_{3}(A-a)=P_{2} A
$$

$F_{k}$ は次の式(3)により定義される.

$$
F_{k}=k(l-\Delta L)
$$

また，人工筋肉の収縮による力 $F_{m}$ は，軸方向繊維強化型 人工筋肉の力学的平行モデル ${ }^{9)}$ により式(4)のように表せる. $G_{I,} G_{2,} G_{3}$ は人工筋の仕様と収縮量から定まる定数である.

$$
F_{m}\left(\Delta L, P_{3}\right)=\left\{P_{3} G_{3}(\Delta L)-G_{1}(\Delta L)\right\} / G_{2}(\Delta L)
$$

式(2)-(4)より, 吐出圧力は式(5)のように表せる.

$$
\begin{aligned}
P_{2}= & \left\{P_{3} G_{3}(\Delta L)-G_{1}(\Delta L)\right\} G_{2}(\Delta L)^{-1} A^{-1}+k A^{-1} \\
& (l-\Delta L)+P_{3} A^{-1}(A-a)
\end{aligned}
$$

式(5)を用いて, 本ポンプの吐出流量と吐出圧力の関係を 図示したものがFig. 8である. グラフの描画には, Table 4, 5に示すパラメータを用いた. Fig. 8より, ポンプへの供給
圧力に対して吐出圧力が大きく, 高い増圧率を有している ことがわかる，また，本ポンプは吐出圧力が高まるほど吐 出流量が下がることがわかった.

Table 3 Parameters of pressure booster

\begin{tabular}{|l|l|}
\hline$D$ & Diameter of tube $[\mathrm{mm}]$ \\
\hline$L$ & Length of tube $[\mathrm{mm}]$ \\
\hline$\Delta L$ & Shrinkage of tube $[\mathrm{mm}]$ \\
\hline$l$ & Maximum shrinkage of tube $[\mathrm{mm}]$ \\
\hline$A$ & Piston area of cylinder $\left[\mathrm{mm}^{2}\right]$ \\
\hline$a$ & Cross sectional area of cylinder rod $\left[\mathrm{mm}^{2}\right]$ \\
\hline$P_{0}$ & Atmospheric pressure $[\mathrm{MPa}]$ \\
\hline$P_{1}$ & Pressure of inflow $[\mathrm{MPa}]$ \\
\hline$P_{2}$ & Pressure of outflow $[\mathrm{MPa}]$ \\
\hline$P_{3}$ & Pressure of pressure booster $[\mathrm{MPa}]$ \\
\hline$k$ & Spring constant $[\mathrm{N} / \mathrm{mm}]$ \\
\hline
\end{tabular}

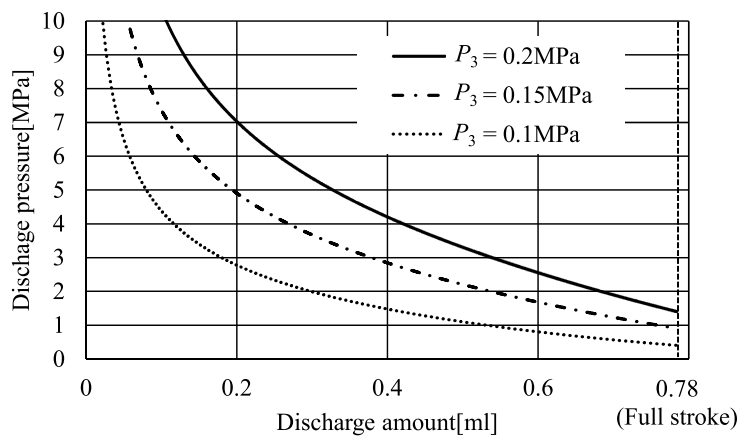

Fig. 8 Discharging amount and pressure

\section{3 プロトタイプ}

制作したプロトタイプの外観をFig. 9に，仕様をTable 4 に示す。シリンダはSMC製単動シリンダCJPB10-10を用い た. 軸方向繊維強化チューブはNRゴムとマイクロカーボ ン繊維で構成され, 内径 $10 \mathrm{~mm}$, 外形 $13 \mathrm{~mm}$, 長さ $45 \mathrm{~mm}$ である.

\section{4 特性実験}

試作した増圧装置の, 最大流量吐出時における吐出圧力 を測定し, 理論值との比較を行う. 実験環境をFig. 10に示 す. ポンプへの流入液体の圧力を一定とし, 増圧ポンプを 繰り返し駆動させ，ポンプの吐出流量が最大ではなくなっ た時点での容器内圧力を圧力計で測定した. なお, ポンプ

Table 4 Specification of the pressure booster

\begin{tabular}{|l|l|}
\hline Size & $210 \mathrm{~mm} \times 20 \mathrm{~mm} \times 30 \mathrm{~mm}$ \\
\hline Weight & $122 \mathrm{~g}$ \\
\hline Discharge amount of cylinder & $0.78 \mathrm{~mL}$ \\
\hline Spring constant of cylinder & $0.49 \mathrm{~N} / \mathrm{mm}$ \\
\hline
\end{tabular}




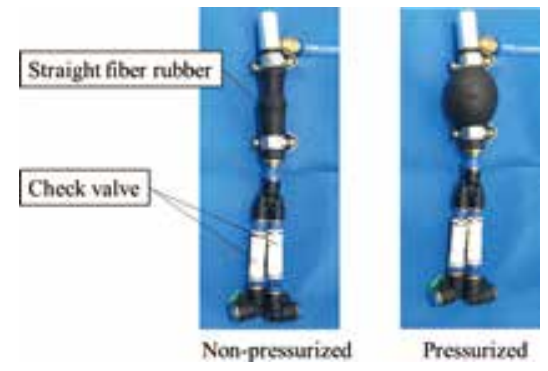

Fig. 9 Image of pressure booster

が最大吐出流量を吐出しているかどうかは，シリンダロッ ドとシリンダが衝突する音によって判断した．流入液体の 圧力は0.1MPaから0.2MPaまで0.025MPaずつ変化させた．増 圧ポンプの駆動にはラバーアクチュエータの排気は使用せ ず，別途用意した空気圧源から $0.1 ， 0.15 ， 0.2 \mathrm{MPa}$ の 3 通りの 圧力を加えて実験を行った．実験結果をFig. 11に示す．図 中の理論值は, 式(5)を用いて最大吐出量での吐出圧力を算 出したものである．測定值は理論值をやや下回っているも のの, 3.2で導出したモデルが本増圧装置の特性を表してい ることが確認できた，また，理論值との差については，増 圧装置に用いたウレタンチューブの弾性変形が主な要因で あると考える。

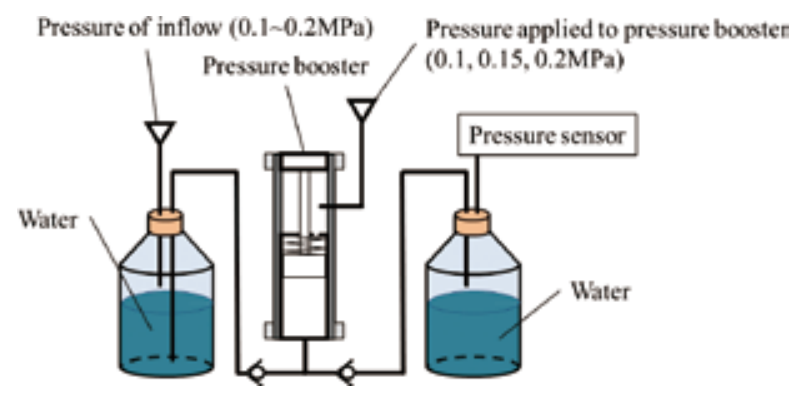

Fig. 10 Experimental set up

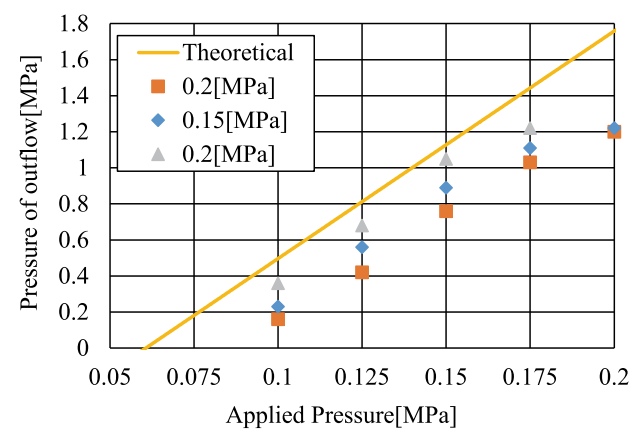

Fig. 11 Characteristics of pressure booster

\section{4. 人工筋肉駆動実験}

\section{1 実験条件}

提案システムの有効性を確かめるため，人工筋肉駆動実 験を行った，実験装置をFig. 12に示す，な㧍，システム構 成はFig.7と同様である．実験装置の設定および使用した
物質の分量をTable 5に示す. 実験では， 3 方弁と 2 方弁を 周期10s，デューティ比50\%のパルス信号で同時に駆動した. 本操作により人工筋肉と増圧装置が交互に駆動され, 増圧 装置が駆動されるごとにクエン酸飽和水溶液がボトルBに 注入される. また, 実験開始直後から人工筋肉の駆動及び クエン酸水溶液の注入が開始するように，ボトルAを $0.15 \mathrm{MPa}$ ，ボトルBを0.35MPaにあらかじめ加圧した。 なお， 本実験で使用したクエン酸および炭酸水素ナトリウムの分 量は, 6.72NLの二酸化炭素を発生可能な物質量であり, こ れは本実験で使用する人工筋肉を 44 回駆動することが可能 である。

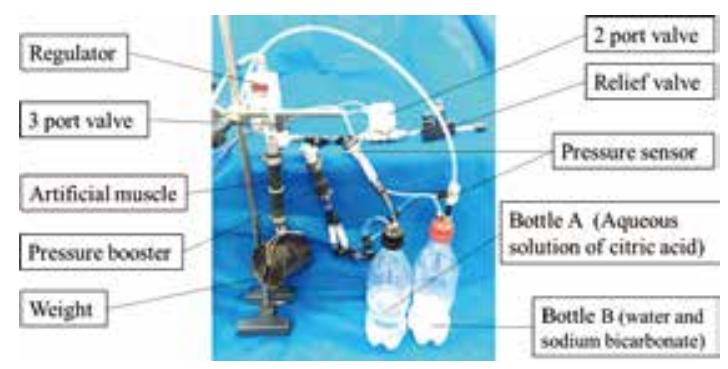

Fig. 12 Experimental setup

Table 5 Experimental conditions

\begin{tabular}{|l|l|}
\hline Amount of citric acid in bottle A & $19.2 \mathrm{~g}$ \\
\hline Water in bottle A & $26 \mathrm{~mL}$ \\
\hline Sodium bicarbonate & $25.2 \mathrm{~g}$ \\
\hline Water in bottle B & $24 \mathrm{~mL}$ \\
\hline Volume of bottle A & $0.5 \mathrm{~L}$ \\
\hline Volume of bottle B & $0.5 \mathrm{~L}$ \\
\hline Volume of artificial muscle (pressurized) & $0.15 \mathrm{~L}$ \\
\hline Mass of weight & $1.7 \mathrm{~kg}$ \\
\hline Driving pressure of artificial muscle & $0.225 \mathrm{MPa}$ \\
\hline
\end{tabular}

\section{2 結果と考察}

実験の様子をFig. 13に示す，人工筋肉と増圧装置が交互 に加圧されている様子が確認できる．なお，人工筋肉は 1 サイクル毎に重りを $15 \mathrm{~mm}$ 持ち上げることを確認した. Fig. 14はボトルB内の圧力について, 本実験の結果と, 増 圧システムを用いずにボトルBにあらかじめ充填された圧 力のみにより人工筋肉を駆動させた場合との比較である. 比較結果からわかるように, 増圧システムを用いない場合 の人工筋肉駆動回数が 6 回であるのに対し, 提案システム は23回の駆動が可能であり, 提案手法により人工筋肉を $0.225 \mathrm{MPa}$ の印加圧力で 17 回駆動させるだけの圧縮空気が生 成されたことが確認できた。本実験において気体発生に使 用したクエン酸，水，炭酸水素ナトリウムの総質量は $94.4 \mathrm{~g}$ であるため, 人工筋肉を一回駆動させるために, 約 $5.6 \mathrm{~g} の$ 


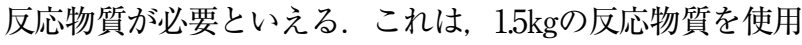
したとすると約268回の駆動が可能であり，たとえば30sに 一回人工筋肉を駆動させる作業を想定した際に，134min使 用可能となり十分使用に耐える時間と考える.

Fig. 15はボトルA内圧力および増圧装置駆動圧力である. ボトルA内の圧力が人工筋肉駆動圧力を下回ると同時に, 増圧装置への供給圧力も低下し, ボトル A内圧力の上昇が 鈍化することが確認できる.これは，ボトルA内に注入さ れるクエン酸飽和水溶液の量が増圧装置の駆動圧力の低下 に伴い減少するからである。

本実験で人工筋肉を駆動できた回数は23回であり，4.1で 算出した44回に対し少ない回数であった．要因はクエン酸 と炭酸水素ナトリウムが完全に反応していないことと考え る.これは，実験終了後にボトルを振った際にボトルA内 圧力が再び人工筋肉駆動圧力以上に上昇したことからも確 認できた。

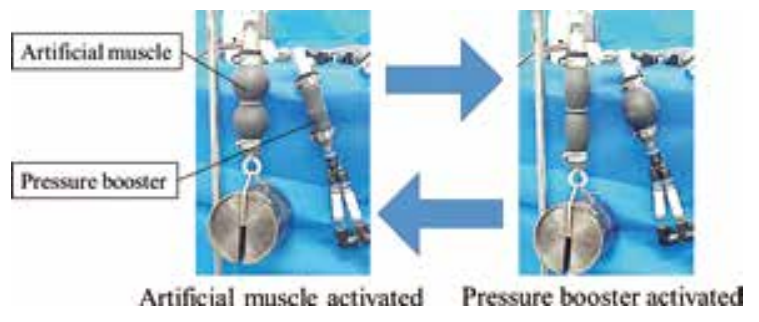

Fig. 13 Image of experiment

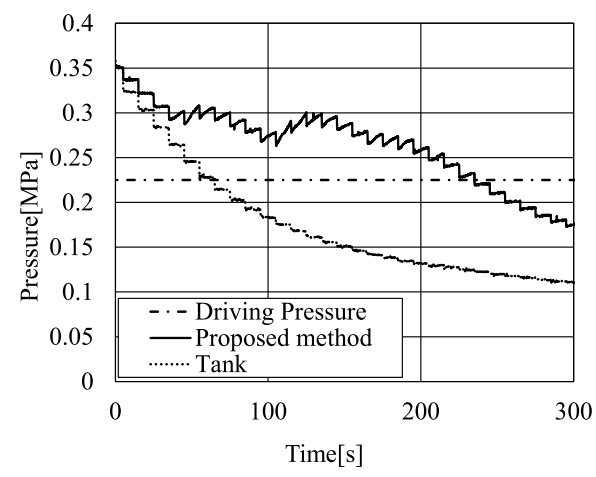

Fig. 14 Pressure in bottle A

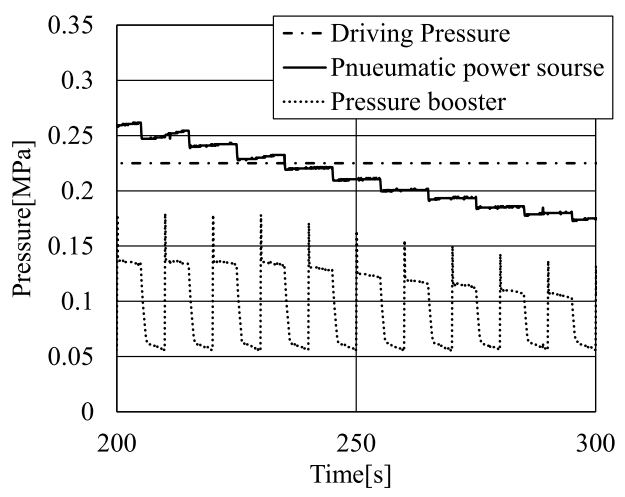

Fig. 15 Pressure to pressure booster and in bottle B

\section{5. 結言}

化学反応を利用した圧縮空気生成手法と, 増圧装置によ り化学反応を継続させるシステムを提案した。 また試作機 による実験を行い，提案システムの動作を確認した。

今回行った実験は, 小型のアクチュエータで評価を行っ ており，実際のシステムの消費空気量よりも小さい．今後 は増圧ポンプを大型化する, 振動を加えて化学反応を促進 するなどの手法により流量増加が期待できる.

謝辞

本研究は, 国立研究開発法人 新エネルギー・産業技術総 合開発機構（NEDO）の支援により実施された。

\section{参 考 文 献}

1) C. T. Loh, H. Tsukagoshi, "Pneumatic Big-hand Gripper with Slip-in Tip Aimed for the Transfer Support of the Human Body", IEEE International Conference on Robotics \& Automation (ICRA), 475-481 (2014)

2 ) D. Sasaki, T. Noritsugu and M. Takaiwa, "Development of Active Support Splint driven by Pneumatic Soft Actuator(ASSIST)", IEEE International Conference on Robotics and Automation Barcelona, 520-525 (2005)

3 ）則次俊郎, 韓建海, 高岩昌弘, “電磁石型リニア駆動 小型コンプレッサの開発”， 日本フルードパワーシス テム学会論文集, vol. 33, No. 4, p. 83-90（2002）

4) R. F. Shepherd, A. A. Stokes, J. Freake, J. Barber, P. W. Snyder, A. D. Mazzeo, L. Cademartiri, S. A. Morin and G. M. Whitesides," Using Explosions to Power a Soft Robot", Wiley-VCH Verlag GmbH \& Co. KGaA, Weinheim, 29642968 (2013)

5 ) K. Suzumori, A. Wada and S. Wakimoto, "A new mobile pressure control system for pneumatic actuators using reversible chemical reactions of water," IEEE/ASME International Conference on Advanced Intelligent Mechatronics (AIM), 122-127 (2013)

6）北川能，吳海帆，塚越秀行，朴聖煥，“三重点に㧈ける相 変化を利用した携帯型空気圧源の開発”，日本フルードパ ワーシステム学会論文集，vol. 36, No. 6, p. 16-22，(2003)

7）多田隈建二郎，多田隈理一郎，緒方裕彦，越智康平, 東森充, 金子真, “爆発的混合反応を活用した高圧気体 発生機構”, 第29回日本ロボット学会学術講演会講演論 文集，1P1-5 (2011)

8）山本孝之，鈴森康一，山田嘉昭，脇元修一，武藤明徳, “化学反応による空圧アクチュエータ用携帯ガス圧源 の開発”, 日本機械学会第22回バイオエンジニアリン グ学会講演論文集, 111 (2010)

9) T. Nakamura, D. Tanaka, H. Maeda, “Joint stiffness and 
position control of artificial muscle manipulator using

instantaneous loads using a mechanical equilibrium model," Advanced Robotics, vol. 25, pp. 387-406 (2011) 